\title{
Dywersyfikacja produktu turystycznego a zmiany układów przestrzennych zagospodarowania turystycznego Malty
}

\section{Diversification of tourist product vs. changes in the spatial systems of tourist development of Malta}

Streszczenie: Współcześnie turystyka stała się w wielu obszarach świata wiodącym działem gospodarki. Jest ona szansą na aktywizację zawodową ludności, zwiększenie dochodów oraz intensyfikację zagospodarowania infrastrukturalnego. W przypadku regionów turystycznych, które wyspecjalizowały się w turystyce wypoczynkowej, pojawia się ważne pytanie dotyczące dalszych tendencji rozwojowych, które zapewnią podtrzymywalność lokalnego rozwoju turystyki. Jednym ze sposobów na utrzymanie lub zwiększenie znaczenia turystyki jest dywersyfikacja produktu w oparciu o nowe rodzaje ruchu turystycznego. Konsekwencją tych działań są zmiany w strukturze i typach zagospodarowania turystycznego, które stwarzają możliwości pozyskiwania nowych klientów. Malta dysponuje atrakcyjnymi warunkami do rozwoju turystyki wypoczynkowej (malownicze plaże, ciepłe, czyste wody morskie), kulturowej (megalityczne kompleksy świątynne, historyczne miasta) oraz lingwistycznej (nauka języka angielskiego). W porównaniu do lat 80 . XX wieku ruch turystyczny wzrósł o ponad połowę, co jest m.in. wynikiem dywersyfikacji produktu turystycznego przez wprowadzenie form turystyki kwalifikowanej (diving, climbing, caving, golf).

\begin{abstract}
At present, tourism has become the leading sector in many geographical locations. It offers the opportunity to activate the local labour force, increase income of the local population and intensify industrial development. In case of tourist regions which specialise in recreation tourism, an important question emerges about the future development trends ensuring sustainability of the local tourist development. A well-proven method to maintain or increase the importance of tourism is to diversify the product based on new types of tourist traffic. Such activities result in changes in the tourist development structures and types, which create opportunities of acquiring new clients. Malta offers attractive conditions for developing recreation tourism (picturesque beaches, clean and warm sea), cultural tourism (megalithic temple complexes, historical cities) and linguistic tourism (language courses). When compared to $1980 \mathrm{~s}$, a $50 \%$ growth in the tourist traffic has been reported, also in consequence of a diversified tourist product through introduction of qualified tourism (diving, climbing, caving, golf).
\end{abstract}

Słowa kluczowe: Malta; małe wyspy; turystyka edukacyjna; turystyka sportowa Keywords: educational tourism; Malta; small islands; sports tourism 
Otrzymano: 10 lutego 2015

Received: 10 February 2015

Zaakceptowano: 7 lipca 2015

Accepted: 7 July 2015

\section{Sugerowana cytacja / Suggested citation:}

Rettinger, R., Kukla, M. (2015). Dywersyfikacja produktu turystycznego a zmiany układów przestrzennych zagospodarowania turystycznego Malty. Prace Komisji Geografii Przemystu Polskiego Towarzystwa Geograficznego, 29(3), 83-96.

\section{WSTĘP}

Przedmiotem opracowania jest analiza kierunków rozwojowych turystyki na Malcie w kontekście kurczących się zasobów przestrzeni geograficznej. Głównym jego celem jest próba określenia kierunku rozwojowego w aspekcie trwałości rozwoju regionu. Dla osiągnięcia i utrzymania przewagi konkurencyjnej w stosunku do innych obszarów basenu Morza Śródziemnego ważne są długoterminowe planowanie i kontrola na różnych poziomach. Malta w niniejszym opracowaniu jest traktowana jak dojrzały obszar turystyczny (zakres pojęciowy zostanie określony w dalszej części opracowania), w związku z tym kluczowym pytaniem badawczym jest to, jakie mechanizmy należy uruchomić, aby podtrzymać lokalny i regionalny rozwój turystyki.

Problem rozwoju turystyki na obszarach wyspiarskich jest analizowany z uwzględnieniem różnych perspektyw badawczych. Jednoznacznie można stwierdzić, że w wielu obszarach świata intensywny rozwój turystyki zadecydował o jej janusowym obliczu. Oczywiście, turystyka przynosi wymierne korzyści środowiskowe, społeczne i ekonomiczne, ale nieumiejętnie kierowana generuje niekorzystne skutki (Boissevain, 1979). W przypadku małych wysp dyskutowany jest problem zawłaszczania terenów pod zabudowę infrastrukturalną. Drugim bardzo ważnym kierunkiem badawczym jest aspekt ekonomiczny rozwoju turystyki, a w szczególności uzależnienie bardzo wrażliwych gospodarek od turystyki i ekonomicznego ryzyka inwestycji zagranicznych w turystyce (Hotia, McAleera, Shareef, 2007; Oglethorpe, 1985).

Podstawowe materiały zostały zebrane w trakcie półrocznych badań terenowych na wyspie, pomocne były także materiały statystyczne i kartograficzne opublikowane na stronie Malta Tourism Authority (Tourism in Malta, 2014).

\section{ROLA TURYSTYKI W SYSTEMIE GOSPODARCZYM WYSPY}

Gospodarka turystyczna od wielu lat stanowi najistotniejszy element gospodarki tego niewielkiego kraju (316 km²), zamieszkałego przez 450 tys. osób. W 2012 roku 30\% PKB stanowiły przychody z turystyki. Około 8,5\% siły roboczej Republiki Malty znajduje zatrudnienie w turystyce, co przekłada się mniej więcej na 12,5 tys. pracowników (jeden z najwyższych wskaźników w Europie). Według szacunków National Commission for Higher 
Education (NCHE) w 2015 roku wzrośnie zapotrzebowanie na pracowników w branży turystycznej o kolejne 5,4 tys. Aktualnie 4\% pracowników zatrudnionych w turystyce posiada wyższe wykształcenie, a $71 \%$ ma niskie kwalifikacje. W branży turystycznej działa ok. 4,5 tys. przedsiębiorstw.

Malta charakteryzuje się bardzo dobrym zagospodarowaniem turystycznym. W 2013 roku zarejestrowanych było 196 obiektów noclegowych, w tym: 135 hoteli (34 tys. miejsc noclegowych), jedna wioska turystyczna (600 miejsc noclegowych) oraz 60 domów gościnnych (2,8 tys. miejsc noclegowych). Całkowita liczba miejsc noclegowych w tych obiektach wyniosła 37,8 tys. Powyższa liczba nie zawiera miejsc dostępnych w hostelach, apartamentach wakacyjnych czy willach wakacyjnych.

W przypadku hoteli największym potencjałem miejsc noclegowych dysponują obiekty czterogwiazdkowe (14,8 tys.), trzygwiazdkowe (10,8 tys.) oraz pięciogwiazdkowe (7,2 tys.). Ten potencjał przekłada się na ich wykorzystanie, ponieważ najwięcej noclegów udzielono w obiektach czterogwiazdkowych - 3,8 mln, trzygwiazdkowych - 1,8 mln oraz pieciogwiazdkowych - 1,6 mln.

Od początku lat 90. liczba turystów zagranicznych na Malcie utrzymuje się powyżej miliona rocznie, a w ostatnim roku zanotowano aż 1582153 przyjazdów (tab. 1).

Tab. 1. Liczba przyjazdów turystów zagranicznych na Maltę w latach 2006-2013

\begin{tabular}{|l|c|c|c|c|c|c|}
\cline { 2 - 7 } \multicolumn{1}{c|}{} & 2006 & 2008 & 2010 & 2011 & 2012 & 2013 \\
\hline $\begin{array}{l}\text { przyjazdy } \\
\text { turystów } \\
\text { (w osobach) }\end{array}$ & 1124233 & 1290856 & 1336341 & 1411748 & 1443414 & 1582153 \\
\hline $\begin{array}{l}\text { łączna liczba } \\
\text { udzielonych } \\
\text { noclegów }\end{array}$ & 10661387 & 10962465 & 11139826 & 11680167 & 11859521 & 12890268 \\
\hline
\end{tabular}

Źródło: opracowanie własne na podstawie: Tourism industry sub-sectors (2014) oraz Tourism in Malta (2014)

Do głównych cech charakterystycznych maltańskiego rynku turystycznego należą obecność niewielkiej liczby zagranicznych touroperatorów oraz niewielka ilość rynków źródłowych, w których dominującą rolę odgrywa Wielka Brytania. Do 1960 roku wyspa była zależna od Wielkiej Brytanii, a do dzisiaj mieszkańcy posługują się językiem angielskim, który jest jednym z dwóch języków urzędowych (obok maltańskiego). Rocznie na wyspę przyjeżdża około 450 tys. Brytyjczyków i wielkość ta utrzymuje się na stałym poziomie. Drugim krajem generującym ruch turystyczny są Włochy (233 tys. w 2013 roku). Dla obywateli tego kraju istotna jest niewielka odległość dzieląca ich od Malty i wiele możliwości dotarcia na nią, ponieważ poza licznymi połączeniami lotniczymi państwa te łączy szlak morski, popularny wśród turystów (Sycylia-Malta). Powyżej 100 tys. turystów rocznie przyjeżdża jeszcze z Niemiec, krajów skandynawskich i Francji (Tourism industry sub-sectors, 2014; Tourism in Malta, 2014).

W przypadku Malty można wyróżnić 6 głównych regionów turystycznych (ryc. 1). Są to: Gozo i Comino; Mellieha; Półwysep Qawra (Bugibba, Qawra, St. Paul’s Bay); Zatoka 
Golden Bay, centrum kultury i rozrywki (Valletta, Sliema, St. Julians) oraz wschód wyspy (ryc. 1). W obrębie wyżej wymienionych regionów koncentruje się większość obiektów noclegowych (133 ze 135).

Ryc. 1. Główne formy użytkowania terenu Malty
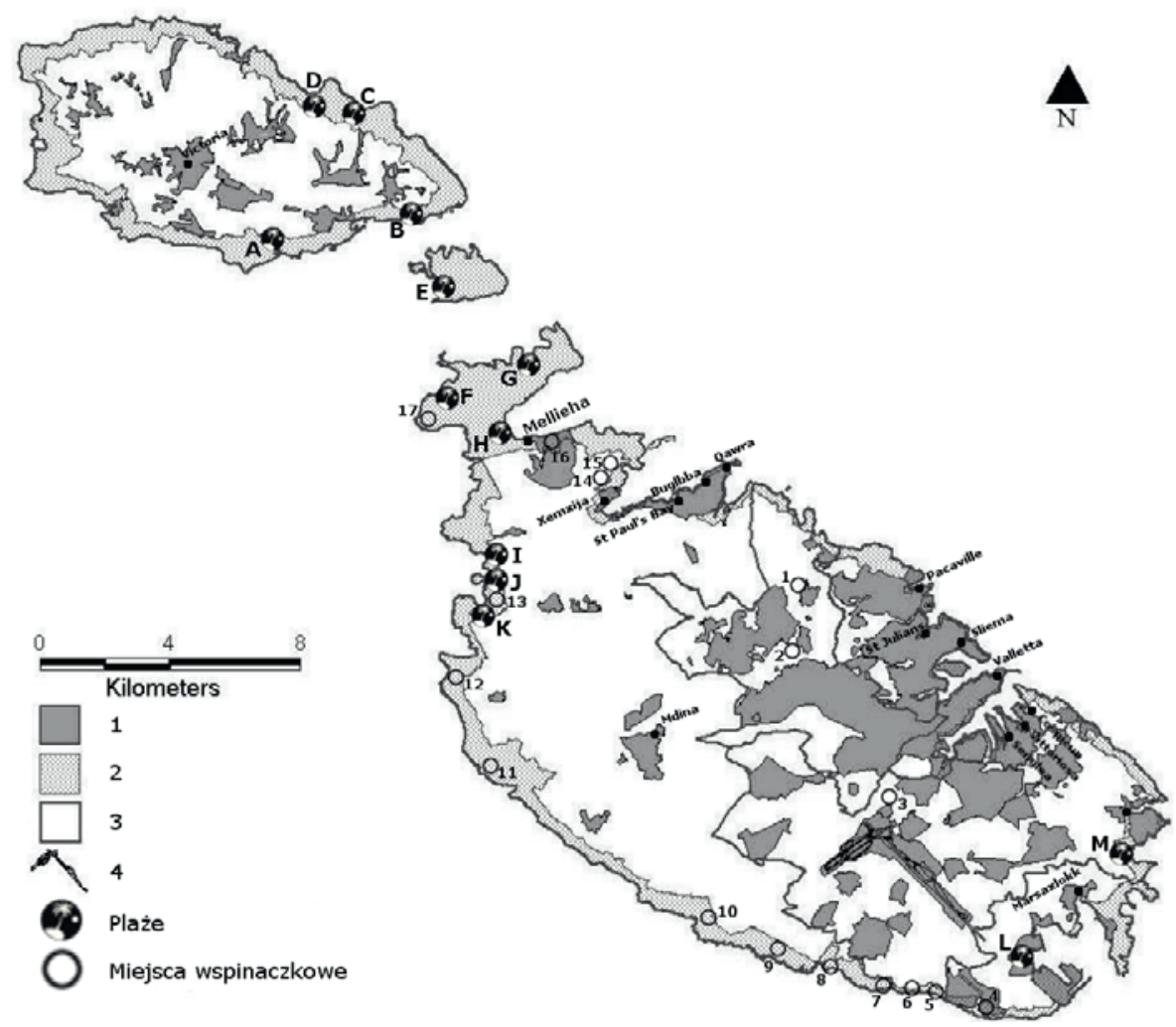

Legenda

Kwadraty: 1 - obszary zabudowane; 2 - obszary nadbrzeżne; 3 - obszary niezabudowane; 4 - lotnisko;

Plaże: 1 - Golden Bay; 2 - Ghajn Tuffieha; 3 - Gnejna; 4 - Blue Lagoon; 5 - Mellieha Bay; 6 - Ramla Bay; 7 Mgarr Ix-Xini; 8 - Paradise Bay; 9 - Hondoq ir-Rummien; 10 - San Blas; 11 - St Thomas Bay; 12 - Pretty Bay; 13 - Armier Bay

Miejsca wspinaczkowe: 1 - Victoria Lines; 2 - Wied il-Ghasel; 3 - Wied Qirda; 4 - Ghar Hasan; 5 - Wied il-Bassasa; 6 - Continuation Wall; 7 - Wied Babu; 8 - Hamrija Tower Slabs; 9 - Ghar Lapsi; 10 - Ix-Xaqqa; 11 - Migra I-Ferha; 12 - Fomm ir-Rih; 13 - Il-Karraba; 14 - Rdum Rxawn; 15 - Irdum Irxaw; 16 - Mellieha; 17 - Il-Latnija \& Il-Qammiegh

Źródło: opracowanie własne na podstawie http://www.mepa.org.mt/

W strategii rozwojowej turystyki na Malcie najwyższą pozycję zajmuje turystyka wypoczynkowa (oparta na zasadzie 3S i wysokiej jakości świadczonych usług), w dalszej kolejności znajdują się turystyka kulturowa, edukacyjna i sportowa. Od kilku lat utrzymuje się 
tendencja do wspierania rozwoju turystyki przez rządowe i pozarządowe agendy. Jednym z priorytetów jest dywersyfikacja produktu turystycznego rozumiana jako różnorodność form ruchu turystycznego. W strategii rozwojowej turystyki na Malcie zostały określone kluczowe obszary działań, do których należą:

- poszukiwanie nowych regionów generujących ruch turystyczny (za najważniejsze uznano Polskę i Izrael),

- zmniejszenie zjawiska sezonowości ruchu turystycznego przez przygotowanie oferty turystycznej możliwej do realizacji w okresie zimowym,

- zwiększenie lotniczej dostępności zewnętrznej,

- poszukiwanie rynków i produktów niszowych,

- dalsza promocja turystyki kulturowej w oparciu o potencjał turystycznych miast,

- zwiększanie turystyki przyjazdowej z Wielkiej Brytanii przez ukierunkowane kampanie marketingowe,

- rozwój cruisingu.

Powyższe działania mają swoje umocowanie w fakcie braku nowych terenów pod rozwój infrastruktury turystycznej, a także w polityce zrównoważonego rozwoju.

\section{HISTORYCZNY CHARAKTER ROZWOJU PRODUKTU TURYSTYCZNEGO}

Od początku lat 60. turystyka miała pierwszoplanowe znaczenie w rozwoju społecznogospodarczym kraju. W 1964 roku Malta uzyskała niepodległość; w ten sposób skończyła się długoletnia zależność od Wielkiej Brytanii. Bardzo ważnym momentem w rozwoju turystyki na wyspie było zamknięcie baz wojskowych w 1979 roku. Ten fakt spowodował szereg konsekwencji dla sytuacji społeczno-gospodarczej wyspy, co przejawiało się utratą miejsc pracy i spadkiem wpływów budżetowych. W ten sposób turystyka wraz z przemysłem włókienniczym i odzieżowym stały się głównymi miejscami zatrudnienia (King, 1979; Lockhart, Mason, 1989). Jeszcze jednym bardzo ważnym efektem likwidacji brytyjskich baz wojskowych były zmiany przestrzenne, a w szczególności konieczność zagospodarowania terenów zajętych wcześniej przez wojsko. Obszary te poddano rewitalizacji, w wyniku której nastąpiła radykalna zmiana ich funkcji.

Jeszcze na początku lat 60. Malta dysponowała zaledwie 26 hotelami o pojemności 1,388 tys. miejsc noclegowych (Hotia, McAleera, Shareef, 2007). Ta sytuacja wymagała radykalnej zmiany. Do 1964 roku rozwój zagospodarowania przestrzennego był w dużym stopniu zależny od decyzji zewnętrznych (Wielka Brytania); w tym okresie znaczną część wyspy zajmowały brytyjskie bazy wojskowe (np. Pembroke). Lata 80. i 90. oznaczały dla wyspy imperatyw dynamicznego rozwoju turystyki, przy równoczesnym braku długofalowych i kompleksowych planów przestrzennego zagospodarowania kraju. Proces ten trwał do początku lat 90. (Beeley, Charlton, 1994), kiedy to wprowadzono regulacje prawne dotyczące takich planów. W wyniku przestrzennego rozwoju turystyki doszło do polaryzacji zagospodarowania turystycznego. Ruch turystyczny koncentruje się w kilku regionach: Sliema, St. Julians, Bugibba, St. Paul's Bay, Marsaskala, Marsalforn na Gozo. 
Duże zainteresowanie wyspą przejawiało się także w rozwoju budownictwa mieszkaniowego, a wynikało to z faktu migracji mieszkańców z zatłoczonych centralnych części miast do stref podmiejskich. Dodatkowo proces ten zaczął się nasilać wraz ze wzrostem zainteresowania Brytyjczyków zakupem nieruchomości na terenie wyspy. Powyższe fakty przyczyniły się do intensywnego zajmowania nowych obszarów pod zabudowę mieszkaniową (Beeley, Charlton, 1994).

Już na początku 2001 roku na stronie Malta Environment and Planning Authority zawarto szereg niepokojących stwierdzeń dotyczących wielkości zagospodarowania i ruchu turystycznego w kontekście zbliżania się do granicy pojemności i chłonności turystycznej. Te fakty wymusiły na władzach różnych szczebli zmianę dalszej strategii rozwojowej turystyki na Malcie, szczególnie w jej aspekcie przestrzennym. W tym momencie pojawiła się konieczność „wstrzemięźliwości konsumpcyjnej” przestrzeni geograficznej jako gwarancji dalszego rozwoju turystyki.

Należy postawić pytanie, czy Maltę można uznać za obszar turystycznie dojrzały. Za M. Miką (2014) można przyjąć, że warunkiem uznania jej za taki obszar jest sytuacja, w której nie obserwuje się już wyraźnego przyrostu liczby przyjezdnych turystów ani pojemności recepcyjnej. Opisuje ją stan relatywnej równowagi pomiędzy popytem a lokalną podażą miejsc turystycznych, co przyjmuje się jako sytuację stagnacji rozwojowej. Na tej podstawie można mówić o zahamowaniu rozwoju turystyki w sensie ilościowym. Taka sytuacja na pewno istnieje w przypadku Malty, gdzie żywiołowy rozwój turystyki, w kontekście rozwoju infrastruktury turystycznej, miał miejsce w latach 90. To doprowadziło do niekontrolowanej zabudowy terenów atrakcyjnych przyrodniczo.

Należy pamiętać, że dojrzałość jest szczególnym stanem rozwoju obszarów turystycznych także w wymiarze przestrzenno-funkcjonalnym, a świadczą o tym następujące cechy (Mika, 2014):

- wykształcony zespół form infrastrukturalnych - architektonicznych, komunikacyjnych i innych, służących realizacji potrzeb turystycznych,

- relatywnie wysoki stopień nasycenia przestrzeni geograficznej obiektami i urządzeniami turystycznymi,

- wewnętrzna złożoność z punktu widzenia powiązań ekonomicznych i społecznych pomiędzy lokalnymi podmiotami sektora turystyki, jak również podmiotami turystycznymi, a innymi sferami życia społeczno-gospodarczego oraz instytucjami władzy miejscowej,

- ciągłość funkcjonalna w sensie historycznym, co oznacza, że w rozwoju można wskazać odróżniające się okresy.

Na Malcie turystyka stanowi strategiczną dziedzinę lokalnej gospodarki, co jest kolejnym argumentem za określeniem jej stanu rozwojowego.

\section{DEFICYT PRZESTRZENI JAKO GŁÓWNA DETERMINANTA ROZWOJU TURYSTYKI}

Malta jako mała wyspa dysponuje stosunkowo ograniczonymi zasobami przestrzeni możliwej jeszcze do zagospodarowania turystycznego. Te ograniczenia wynikają z trzech podstawowych przyczyn: 
- niewielkich rozmiarów wyspy,

- specyficznych warunków środowiska przyrodniczego,

- intensywnej zabudowy mieszkaniowej.

Do głównych form użytkowania terenu Malty należą użytki rolne, które stanowią 51,2\% powierzchni wyspy. W latach 70. i 80. dochodziło do znacznych strat ziemi rolnej przez proces intensywnej zabudowy mieszkaniowej w obszarach podmiejskich oraz przejmowanie terenów pod budowę obiektów infrastruktury turystycznej (obiektów noclegowych). W ciągu ostatnich 30 lat areał użytków rolnych zmniejszył się o 4,4 tys. ha, w latach 1971-1986 średnioroczny ubytek wynosił 213 ha, a w okresie 1986-2001 już tylko 84 ha rocznie. Aktualnie proces ten został zahamowany i obserwuje się wzrost ilości użytków rolnych wynikający z działań zmierzających do ochrony krajobrazu rolniczego wyspy. Stosunkowo niewielki areał zajmują lasy, które stanowią $0,7 \%$ powierzchni wyspy, ale $18,3 \%$ terytorium pokryte jest naturalnymi zbiorowiskami roślinnymi (nieleśnymi).

Bardzo ważnym typem użytkowania terenu są obszary przeznaczone pod zabudowę mieszkaniową; jest to ok. $70,4 \mathrm{~km}^{2}$, co stanowi $22,3 \%$ powierzchni ogólnej. Należy pamiętać, że są to w większości obszary miejskie (wskaźnik urbanizacji - 89,3\%), natomiast niewielkie znaczenie odgrywają tereny wiejskie. Stosunkowo niewielkie rozmiary wyspy oraz liczba ludności decydują o intensywności zabudowy mieszkaniowej, ale nasuwa się pytanie o efektywność jej wykorzystania. Według spisu powszechnego z 2005 roku 22,4\% zasobów mieszkaniowych jest nieobsadzone w sposób trwały, a jedynie 5\% stanowi drugie domy. Powyższa sytuacja wynika w dużej mierze z jakości zasobów mieszkaniowych i warunków życia w centralnych (historycznych) częściach miast i ośrodków turystycznych (Chapman, Speake, 2011; Thake, Hall, 1993). Cechą charakterystyczną maltańskich miast jest nadpodaż lokali mieszkalnych, usługowych i przemysłowych, co jest spowodowane ucieczką ludności z centralnych części miast na obszary podmiejskie oraz emigracją Maltańczyków do innych krajów (np. Wielka Brytania). Dlatego też podjęto szereg działań zmierzających do rewitalizacji historycznych miast Malty, a największe projekty realizowane są w stolicy kraju. Równolegle z procesami odnowy starych, zabytkowych części miasta postępuje proces budowy nowych obiektów mieszkaniowych, przeznaczonych pod wynajem lub na sprzedaż. Bardzo często nowe inwestycje są realizowane w najatrakcyjniejszych turystycznie miejscach, dlatego też podjęto działania planistyczne i legislacyjne zmierzające do ograniczania i pełnej kontroli nowych inwestycji budowlanych pod kątem wizualnym. Najlepszym przykładem tego typu działań są ograniczenia dotyczące wysokości budynków mieszkalnych i usługowych w częściach nadmorskich miast - mogą one mieć od 5 do 15 kondygnacji. Pewnym paradoksem jest fakt, że atrakcyjność turystyczna wyspy spowodowała olbrzymie zainteresowanie tym terenem pod budowę drugich domów czy też apartamentów do wynajmu, a w związku z tym intensywna działalność budowlana bardzo często wpływa negatywnie na walory krajobrazowe nadbrzeżnych części miast.

Bardzo ciekawym zagadnieniem jest rozwój turystyki na wyspie w kontekście rozwoju przestrzennego. Malta ze względu na swoje uwarunkowania środowiskowe jest obszarem trudnym do zagospodarowania turystycznego. Linia brzegowa wyspy jest dobrze rozwinięta, ale wybrzeże ma charakter stromych, klifowych urwisk z licznymi formami 
krasowymi. Ten typ wybrzeża oraz stosunkowo niewielka liczba piaszczystych plaż (11) powodują pewne ograniczenia w rozwoju przestrzennym turystyki, to m.in. doprowadziło do silnej koncentracji bazy turystycznej w północno-wschodniej i wschodniej części wyspy (ryc. 1). Z drugiej strony ten typ wybrzeża decyduje o możliwościach uprawiania turystyki kwalifikowanej.

Dynamiczny rozwój turystyki przyjazdowej w latach 1960-1990 był postrzegany bardzo pozytywnie, jako mechanizm przynoszący gospodarcze korzyści (Bramwell, 2003). Natomiast początek lat 90. spowodował rewizję dotychczasowych opinii w kontekście ograniczonych, a wręcz kurczących się przestrzeni wyspy. Dużym problemem w tym czasie był wzrost terenów zabudowy mieszkaniowej w latach poprzednich, w związku z tym ograniczono wydawanie pozwoleń na budowę (Dodds, 2007).

Koncentracja przestrzenna infrastruktury turystycznej i ruchu turystycznego doprowadziła do znacznego pogorszenia nie tylko wypoczynku, ale także warunków życia ludności miejscowej. Niekontrolowany rozwój zagospodarowania turystycznego spowodował degradację krajobrazu wraz z trwałą utratą obszarów niezabudowanych, zaczęły się też duże problemy z wydolnością systemu wodociągów i kanalizacji (Lockhart, 1997). Pod wpływem presji opinii publicznej podjęto działania zmierzające do zmiany modelu rozwoju turystyki przez zapewnienie trwałości zasobów przyrodniczych, kulturowych, społecznych i gospodarczych (Bramwell, 2003). Coraz częściej pojawiały się negatywne opinie miejscowej ludności dotyczące zawłaszczania przez turystykę nowych terenów, szczególnie rolniczych. Rząd Malty musiał dokonać pewnych zmian w planach przestrzennego zagospodarowania kraju, polegających na ograniczeniu budownictwa zarówno mieszkaniowego, jak i turystycznego. Głównym celem działań w tym zakresie miało być wprowadzenie zmian jakościowych. Rząd wprowadził ścisłą kontrolę gospodarowania gruntami (Boissevain, 1979; Theuma, 2006). Ograniczono także rozwój infrastruktury turystycznej, takiej jak pola golfowe. Zadecydował o tym czynnik środowiskowy, jakim jest deficyt wody na wyspie. Spowodował on także wprowadzenie dodatkowego podatku od basenów, zarówno hotelowych, jak i prywatnych (Dodds, 2007).

Deficyt przestrzeni sprawia, że jednym z możliwych scenariuszy dalszego rozwoju turystyki w regionach dojrzałych jest ich rewitalizacja, zmierzająca do zauważalnego podniesienia poziomu jakości usług turystycznych. Dotyczy to przede wszystkim bazy noclegowej, towarzyszącej i dostępności komunikacyjnej. Aby zahamować spadek liczby przyjazdów, szczególnie turystów zagranicznych, należy podjąć działania zmierzające do poprawy jakości świadczonych usług. Permanentny brak terenów na Malcie wymusza rewitalizację istniejących ośrodków turystycznych, co dotyczy przede wszystkim trzech obszarów: Bugibba, Qawra i St. Julians. Lata 80. charakteryzowały się silną rywalizacją z Hiszpanią, która w tym czasie otworzyła się na rynek brytyjski przez atrakcyjne ceny oraz liczne połączenia lotnicze. Ostra konkurencja w regionie doprowadziła do znacznej obniżki cen wypoczynku na Malcie, co spowodowało ograniczenie środków finansowych przeznaczanych na niezbędne remonty i modernizację bazy noclegowej. Procesem potęgującym problemy związane z przestrzennym zagospodarowaniem wyspy jest brak ładu przestrzennego. Wiele ośrodków turystycznych, np. Bugibba, rozwijało się bardzo chaotycznie, bez jakichkolwiek planów rozwojowych; w dużej mierze pozwolono poszczególnym przedsiębiorcom na samodzielne 
podejmowanie decyzji w sprawie lokalizacji i charakteru inwestycji turystycznych (Cunningham, 2008).

Współczesne działania planistyczne na Malcie zmierzają w trzech głównych kierunkach:

- ograniczenia i ścisłej kontroli działalności budowlanej do tzw. obszarów rozwojowych, a nawet do obszarów chronionego miejskiego krajobrazu (UCA) wytyczonych na terenie wyspy (ryc. 1),

- przeprowadzenia rewitalizacji historycznych części miast, mających na celu nie tylko zmianę ich funkcji, a przede wszystkim podniesienie jakości życia mieszkańców oraz turystów,

- ochrony tradycyjnych wiejskich obszarów ze względu na ich wartość przyrodniczą i kulturową.

\section{DYWERSYFIKACJA PRODUKTU TURYSTYCZNEGO JAKO ELEMENT ZMIAN} STRUKTURALNYCH

Ekonomiczna funkcja turystyki jest jedną z najważniejszych korzyści regionów turystycznych, ale kierowanie się tylko tą prostą zasadą może doprowadzić do upadku tej funkcji turystycznej w regionie, co dotyczy zwłaszcza takich obszarów turystyki wypoczynkowej jak Malta. Dlatego też wszystkim działaniom powinna przyświecać idea podtrzymywalnego rozwoju turystyki, który gwarantuje korzyści dla turystów, ale przede wszystkim dla społeczności lokalnych. Dynamiczny, nieplanowany i niekontrolowany rozwój turystyki na Malcie doprowadził do powstania wielu konfliktów przestrzennych wynikających z zawłaszczania nowych terenów pod infrastrukturę turystyczną. Lata 90. oznaczały dla Malty zasadniczą zmianę planów przestrzennego zagospodarowania kraju, wynikającą z deficytu terenów oraz pogarszających się warunków życia mieszkańców i wypoczynku turystów. Nowy kierunek rozwoju ekonomicznego kraju musiał uwzględniać wiodącą rolę turystyki w generowaniu PKB, w związku z tym pojawiło się pytanie, jak utrzymać stały poziom przyjazdów turystów w warunkach silnej konkurencji w basenie Morza Śródziemnego. U podstaw nowych koncepcji rozwojowych pojawiło się założenie dotyczące deficytu przestrzeni, które wymusiło działania zmierzające do zmian strukturalnych. Dotyczyły one zarówno infrastruktury turystycznej (wydawanie pozwoleń na budowę tylko hoteli najwyższych kategorii), jak i segmentacji rynku turystycznego. Podjęto decyzję o konieczności poszukiwania nowych klientów, którzy spowodują racjonalizację wykorzystania istniejącego potencjału rozwojowego wyspy. W związku z tym wzmocniono pozycję turystyki sportowej jako jednego z najważniejszych segmentów maltańskiego rynku turystycznego (Bull, Weed, 1999).

Łagodny klimat Malty sprawia, że kraj ten jest idealnym miejscem na obozy szkoleniowe i turnieje sportowe rozgrywane w miesiącach zimowych. Ten potencjał nie jest jednak wykorzystywany głównie z powodu braku obiektów sportowych przystosowanych do tego typu imprez. Inwestycje wykonane w ostatnich latach pokazały, że mogą przyciągać zainteresowanych turystów sportowych z całej Europy, zarówno tych indywidualnych, jak i grupowych.

Jednym z działań zmierzających do zmian w gospodarce turystycznej polegających na stworzeniu nowej jakości jest wybudowanie nowego centrum sportowego. Najnowszy 
projekt rządowy zapowiada utworzenie narodowej wioski sportowej - Marsa Sports Village. Projekt ten ma składać się zarówno z obiektów odkrytych (stadion rugby, trawiaste boisko przeznaczone do uprawiania różnych sportów, korty tenisowe oraz boiska do sportów plażowych), jak i krytych, w których można będzie uprawiać kilkanaście różnych dyscyplin sportowych. Projekt ten ma być inwestycją wartą ok. $200 \mathrm{mln}$ euro, która finalnie utworzy kilkaset nowych miejsc pracy. W ramach projektu powstanie czterogwiazdkowy hotel mogący pomieścić uczestników międzynarodowych zawodów sportowych oraz obozów sportowych. Inwestycja pozwoli na rozwój turystyki sportowej na wyspie oraz umożliwi organizację większej liczby imprez sportowych przyciągających turystów oraz grupy sportowe nastawione na trening połączony z wypoczynkiem na Malcie. Zrealizowanie tego projektu jest bardzo istotne dla przyszłego rozwoju turystyki sportowej na wyspie, ponieważ utworzy on pierwszą na Malcie destynację odpowiadającą całościowo turystyce sportowej.

Turystyka sportowa, skierowana głównie do młodzieży, generuje zapotrzebowanie na określony rodzaj zakwaterowania zbiorowego, który nie jest dostatecznie dostępny na Malcie. Chodzi o obiekty z pokojami wieloosobowymi, mogące pomieścić całe zespoły sportowe, wyprofilowane na tego typu gości. Maltańskie Ministerstwo Turystyki w czteroletnim planie (2012-2016) ogłosiło działania marketingowe, mające na celu przyciągnięcie większej ilości turystów sportowych, i inwestycyjne w obiekty mogące zagwarantować odpowiedni typ zakwaterowania dla zespołów sportowych. Nowe obiekty sportowe powinny wzbudzić większe zainteresowanie tym niszowym rodzajem turystyki wśród lokalnych hotelarzy i touroperatorów.

Rząd Malty nie tylko podejmuje działania w zakresie pozyskiwania i realizowania nowych inwestycji, które niestety powodują zmiany w sposobach użytkowania ziemi, ale także promuje sporty niewymagające nowych terenów pod zabudowę. W strategii rozwojowej bardzo mocno została osadzona koncepcja turystyki sportowej wykorzystującej naturalny potencjał wyspy, jakim jest chociażby budowa geologiczna i rzeźba terenu strefy wybrzeża. Linia brzegowa Malty jest w 30\% zajęta przez zabudowę, 22\% stanowią nagie skały, a jedynie $30 \%$ to niskie, piaszczyste wybrzeże. W przypadku drugiej wyspy Gozo nagie skały stanowią $62 \%$ linii brzegowej, a niskie, piaszczyste wybrzeże to $16 \%$. Warunki środowiska przyrodniczego (charakter linii brzegowej) ograniczają możliwości bezpośredniej zabudowy obiektami hotelarskimi w pierwszej linii brzegowej, pewne ograniczenia występują także w przypadku występowania naturalnych plaż. W związku z tym Malta chce zaistnieć na europejskim rynku turystycznym jako miejsce, gdzie przez cały rok można uprawiać nurkowanie, wspinaczkę (climbing, hiking, cliff abseiling - zjazdy z klifów, bouldering) oraz rekreację wodną (spływy kajakowe, wakeboarding, narciarstwo wodne, parakiting) i paralotniarstwo. Wyżej wymienione sporty nie wymagają obiektów infrastrukturalnych, a jedynie obsługi instruktorskiej czy też agencji turystycznych organizujących tego typu wyjazdy turystyczne. Bardzo ważnym atutem tego kierunku rozwojowego jest fakt, że główną grupą docelową tego typu turystyki jest klient młodszy i słabiej sytuowany finansowo, co w konsekwencji oznacza korzystanie z niższego standardu bazy noclegowej i gastronomicznej, której nie brakuje na wyspie. Drugim bardzo ważnym argumentem przemawiającym za tego 
typu turystyką jest możliwość uprawiania jej poza wysokim sezonem turystycznym, co może bezpośrednio zniwelować zjawisko sezonowości ruchu turystycznego.

Kolejnym kierunkiem rozwojowym niewymagającym szczególnych inwestycji, a jedynie bazującym na potencjale endogenicznym regionu, jest turystyka edukacyjna, przede wszystkim obozy językowe. W 2012 roku w tym celu na wyspę przyjechało 70 tys. studentów. Należy pamiętać, że znaczny odsetek tego typu turystów odwiedza kraj poza sezonem i korzysta z bardziej ekonomicznych form usług noclegowych i gastronomicznych oraz że forma ta ma charakter wyjazdu grupowego. Turyści przyjeżdżający na Maltę w celach edukacyjnych korzystają z wielu możliwości uprawiania sportów, które są elementem uzupełniającym ofertę podstawową (nauka języka).

\section{DYWERSYFIKACJA PRODUKTU TURYSTYCZNEGO W WARUNKACH SILNEJ KONKURENCJI}

Malta jako jeden z wielu regionów turystycznych basenu Morza Śródziemnego musi dbać o swoją pozycję na międzynarodowym rynku usług turystycznych. Uzyskanie przewagi konkurencyjnej nad innymi obszarami wymaga wielu działań zmierzających m.in. podniesienia jakości świadczonych usług i wdrażania szeregu innowacji mających na celu do pozyskiwanie nowych klientów. Produktem markowym regionu Morza Śródziemnego jest przede wszystkim turystyka wypoczynkowa oraz kulturowa. Silna konkurencja w regionie wymusiła konieczność wprowadzenia produktu uzupełniającego zasadniczą ofertę. W przypadku Malty jest to to turystyka edukacyjna, a zwłaszcza nauka języka angielskiego. Można to określić jako produkt markowy, który na europejskim rynku posiada wysoką pozycję. Utrzymanie przewagi konkurencyjnej wymaga ciągłych zabiegów zmierzających w konsekwencji do podtrzymania rozwoju turystyki w regionie. W tym przypadku należy podjąć działania, które pozwolą odróżnić Maltę jako region turystyczny od marek produktów analogicznych. Budowanie wizerunku marki w świadomości konsumentów określa się mianem rynkowego pozycjonowania, które jest definiowane jako działanie związane z kształtowaniem oferty i image, prowadzące do zajęcia wyraźnego, znaczącego miejsca w pamięci odbiorców docelowych (Kotler, 1994). Pozycjonowanie marki można więc określić jako proces kreowania i utrwalania pożądanego wizerunku w świadomości docelowych nabywców, aby wyraźnie i pozytywnie odróżniać się od konkurencji. Związane z produktem skojarzenia i przekonania nie dotyczą tylko cech materialnych, takich jak funkcjonalność, niezawodność działania, wygoda stosowania czy łatwość obsługi, ale także pewnych wartości o charakterze społecznym i psychologicznym (Szwajca, 2009).

Jedną z możliwości podtrzymania rozwoju turystyki jest uruchomienie procesu dywersyfikacji produktu turystycznego dojrzałych regionów turystycznych o profilu wypoczynkowym. Te działania będą miały na celu zmianę świadomości klientów jako odbiorców pozycji marki i pozwolą repozycjonować region turystyczny. To w konsekwencji może sprzyjać osiągnięciu i utrzymaniu przewagi konkurencyjnej. Istnieje szereg sposobów repozycjonowania marki, poczynając od zmiany opakowania produktu, przez zmianę cech produktu, a kończąc na zmianie sposobów sprzedaży. Wydaje się być zasadnym stwierdzenie, że w przypadku regionów turystycznych repozycjonowania można dokonać za pomocą zmian cech produktu, 
czyli przez wprowadzenie możliwości rozwoju nowych form ruchu turystycznego. Czy w obecnych czasach największe szanse rozwojowe będą miały regiony charakteryzujące się wysokim stopniem specjalizacji, czy też proponujące potencjalnym turystom szeroką ofertę różnych form wypoczynku, dostosowaną do zmieniających się motywów podróży? Ten dylemat jest trudny do rozstrzygnięcia.

\section{Podsumowanie}

Globalny rynek turystyczny staje się coraz bardziej kapryśny i wymagający, co powoduje konieczność podejmowania działań zmierzających do zaspokojenia rosnącego popytu turystycznego. Przykładem tego typu sytuacji są regiony turystyki wypoczynkowej, które oferują przede wszystkim odpoczynek oparty na zasadzie 3S, ale rosnąca konkurencja oraz nowo powstające regiony powodują, że zmienia się pozycja niektórych z nich (regiony dojrzałe), co skutkuje malejącą wielkością ruchu turystycznego. Oferta musi się zmieniać, ponieważ zmieniają się potrzeby klientów. Konieczna jest dywersyfikacja produktu turystycznego. Te działania korekcyjne mają na celu repozycjonowanie marki. Zmiana może polegać na wprowadzeniu do oferty produktów uzupełniających główny produkt oferowany przez region turystyczny. Bogatsza oferta pozwala na wyróżnienie się spośród konkurencji.

Warunkiem przetrwania i rozwoju wielu regionów turystyki wypoczynkowej będzie ich zdolność konkurowania na rynkach międzynarodowych. Dbałość o środowisko przyrodnicze i zachowanie krajobrazu kulturowego jest olbrzymim atutem pozwalającym osiągnąć przewagę konkurencyjną w przypadku regionów turystycznych. Konkurencyjność jest obecnie coraz bardziej systemowa i środowiskowa, natomiast lokalność jest postrzegana jako ważny zasób, aczkolwiek niejedyny.

W przypadku Malty priorytetem są zmiany strukturalne, a celem - ograniczanie wszelkiego rodzaju zmian przestrzennych. Segmentacja klienta na „bogatszego” i „,biedniejszego” daje większe możliwości kompleksowego wykorzystania potencjału turystycznego regionu, skutkuje także szeregiem pozytywnych zjawisk prowadzących do podtrzymania lokalnego rozwoju turystyki. Głównym celem rozwoju turystyki sportowej na Malcie jest dekoncentracja ruchu turystycznego w północnej i północno-wschodniej części wyspy na rzecz zachodnich i południowo-zachodnich części, które mają optymalne warunki rozwoju różnych form turystyki kwalifikowanej. W związku z tym proces dywersyfikacji produktu turystycznego nie tylko prowadzi do pozyskania nowych klientów, ale też wprowadza zmiany przestrzenne i strukturalne subregionów turystycznych.

Dalszy udział turystyki w generowaniu PKB będzie realizowany przez zwiększającą się liczbę turystów, wspieranie sektora prywatnego w zakresie nowych inwestycji oraz szkolenia pracowników, ale przede wszystkim przez dbałość o elementy środowiska przyrodniczego gwarantujące podtrzymanie rozwoju turystyki w regionie. 


\section{Literatura \\ References}

Beeley, B., Charlton, W. (1994). Maltese Patterns of Dependence: An Historical Perspective. Scottish Geographical Magazine, 110, 112-120.

Boissevain, J. (1979). The impact of tourism on a dependent Island: Gozo, Malta. Annals of Tourism Research, 6, 76-90.

Boissevain, J., Theuma, N. (1998). Contested Space. Planners, Tourists, Developers and Environmentalists in Malta. W: S. Abram, J. Waldren (red.). Anthropological Perspectives on Local Development. Londyn: Routledge, 96-119.

Bramwell, B. (2003). Maltese Response to Tourism. Annals of Tourism Research, 30(3), 581-605.

Bull, C., Weed, M. (1999). Niche markets and small island tourism: the development of sports tourism in Malta. Managing Leisure. 4(3), 142-155. DOI: 10.1080/136067199375814

Chapman, A., Speake, J. (2011). Regeneration in a mass-tourism resort: The changing fortunes of Bugibba, Malta. Tourism Management, 32, 482-491.

Cunningham, A.G. (2008; 2015, 21 stycznia). The resort that Bugibba should be. Available from. Times of Malta. Pozyskano z http://www.timesofmalta.com/articles/view/20081204/letters/the-resortthat-bugibba-should-be.235679

Dodds, R. (2007). Malta'sTourism Policy: Standing Still or Advancing towards Sustainability? Island Studies Journal, 2(1), 47-66.

Hotia, S., McAleera, M., Shareef, R. (2007). Modelling international tourism and country risk spillovers for Cyprus and Malta. Tourism Management, 28, 1472-1484.

King, R. (1979). Developments in the Political and Economic Geography of Malta. Tijdschrift voor Economische En Sociale Geografie, 70, 258-271.

Kotler, P.H. (1994). Marketing od A do Z. Warszawa: Polskie Wydawnictwo Ekonomiczne.

Lockhart, D. (1997). Tourism to Malta and Cyprus. W: D. Lockhart, D. Drakakis-Smith (red.). Island Tourism: Trends and Prospects. Londyn: Pinter, 152-178.

Lockhart, D., Mason, K. (1989). A Social and Economic Atlas of Malta and Gozo. Occasional Paper, 16.

Malta Environment and Planning Authority (2001). Tourism Topic Paper. Pozyskano z https://www. mepa.org.mt/lpg-structureplanreview\#Tourism

Mika, M. (2014). Założenia i determinanty podtrzymywalności lokalnego rozwoju turystyki. Kraków: Instytut Geografii i Gospodarki Przestrzennej Uniwersytetu Jagiellońskiego.

Oglethorpe, M. (1985). Tourism in a small island economy: the case of Malta. Tourism Management, 6, 23-31.

Planning Authority (2000). Structure plan for the maltese islands tourism. Topic study. Final Draft. Pozyskano z http://www.mepa.org.mt/lpg-structureplan.html

Szwajca, D. (2009). Pozycjonowanie marki na rynku globalnym - możliwości i ograniczenia. Economy and Management, 1, 44-59.

Thake, C., Hall, B. (1993). Valletta. Cities. 10, 91-102.

Theuma, N. (2006). Malta: Re-imaging the Mediterranean Destination. W: H. Derek, M. Smith, B. Marciszewska (red.). Tourism in the New Europe: The Challenges and Opportunities of EU Enlargement, 213-224.

Tourism in Malta (2014). Malta Tourism Authority. Pozyskano z http://www.mta.com.mt

Tourism industry sub-sectors (2014; 2015, 22 stycznia). Country Report Malta. Pozyskano z http:// ec.europa.eu/growth/tools-databases/tourism-business-portal/documents/business/internationalisation/malta-country-report.pdf

Renata Rettinger, doktor/adiunkt, Uniwersytet Pedagogiczny w Krakowie, Instytut Geografii. Autorka w swoich badaniach koncentruje się na problematyce rozwoju turystyki w regionie karaibskim. W problematyce badawczej przeważają tematy dotyczące wielkości i przestrzennego zróżnicowania 
zagospodarowania i ruchu turystycznego, a w szczególności kierunki rozwoju turystyki. W opracowaniach przewija się także tematyka enklaw turystycznych jako dominującej formy zagospodarowania turystycznego na Karaibach w kontekście rozwoju zrównoważonego i turystyki pro-poor.

Renata Rettinger, the author in her research concentrates on the problems on tourism development in the Caribbean region. The research issues on the size and spatial differentiation of tourist infrastructure and tourism volume itself together with the directions of the tourism development are dominating. The research topics also include the issue of tourist enclaves as a dominating form of tourist infrastructure in Caribbean in the light of sustainable development and pro-poor tourism.

Maciej Kukla, student turystyki i rekreacji Uniwersytetu Pedagogicznego w Krakowie, absolwent kierunku politologia. Główne zainteresowania to turystyka w basenie Morza Śródziemnego oraz turystyka miejska w Europie.

Maciej Kukla, a student of Tourism and recreation of Pedagogical University of Cracow, graduate of Political Science. His main interests are tourism in the Mediterranean and urban tourism in Europe.

\section{Adres/Address:}

Uniwersytet Pedagogiczny w Krakowie

Instytut Geografii

ul. Podchorążych 2, 30-084 Kraków, Polska

e-mail: maciek.kukla@gmail.com

e-mail: rettinger@onet.eu 